'Imbalances, disparities and disequilibria Europe's and Latin America's social and are amongst the inherent features of economic stagnation is a direct result of the capitalism. How those features play unresolved phenomena of the financialization out in the era of financialization across crisis that broke in 2008 in developed Europe and Latin America are at the countries. Editors Noemi Levy and Etelberto core of this book. There is a rich menu Ortiz analyze the limitations of economic of papers here ranging over what policy growth and development under capitalist and other measures can address the economic organizations where financial capital structural disequilibria in Europe and is dominant, as well as explore alternate impacts of human welfare, the impact of economic policies.

the forces of disequilibria on economic

growth, and deep analyses of many This book argues that institutional settings features of disequilibria in Mexico.' based on the international monetary market, (hat global production organization and the

UK UK $\quad$ be redesigned to improve countries' economic
'As finance emerged to agitate market growth, job opportunities and salaries. In order equilibria, theories of financialization for economic disequilibria to be reduced among have set out to explain that agitation regions, countries and social classes, economic and link it to deflationary and surplus appropriation must be regulated.

distributional trends in our economies. Divided into four distinct thematic sections, the The challenge of financialization lies in chapters discuss how income distribution must the complexity necessary to incorporate be re-evaluated in order to halt the economic finance effectively into models of crisis of developing countries in Europe and production and distribution for Latin America, and to boost a new cycle of economies that have become financial economic growth and development.

centres, as well as for countries where This critical discussion will be of value finance remains weakly developed. The to conomic scholars and researchers, editors and contributors of this book to policymakers wishing to learn mors, have risen to that challenge with a pimitations of economic growth, as woll as volume that lays out the new economics journalists of open economy finance: a volume of first resort for those who wish to

understand international finance today.' Noemi Levy is Professor at the National Jan Toporowski, SOAS, University of Autonomous University of Mexico (UNAM) London, UK, University of Bergamo, and Etelberto Ortiz is Professor at the Italy and International University Metropolitan Autonomous University (UAM) College, Turin, Italy Mexico City.

\section{Edward Elgar}

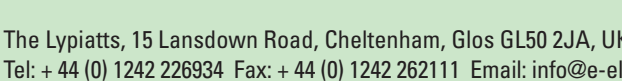
Wilim Prat House Tel: +1 14135845551 Fax: 14135849933 Email: elgarinfo@e-elgar.co www.e-elgar.com www.elgaronline.com

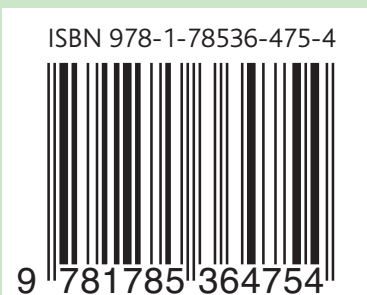

\section{THE FINANCIALIZATION RESPONSE TO ECONOMIC DISEQUILIBRIA}

EE

Elgar

\author{
European and Latin American
}

Experiences

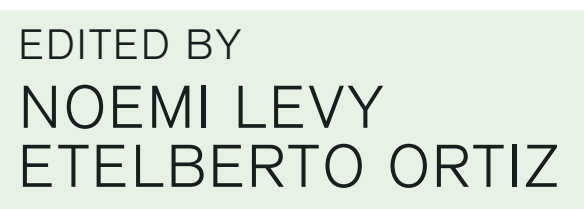

EDITED BY

NOEMI LEVY

ETELBERTO ORTIZ

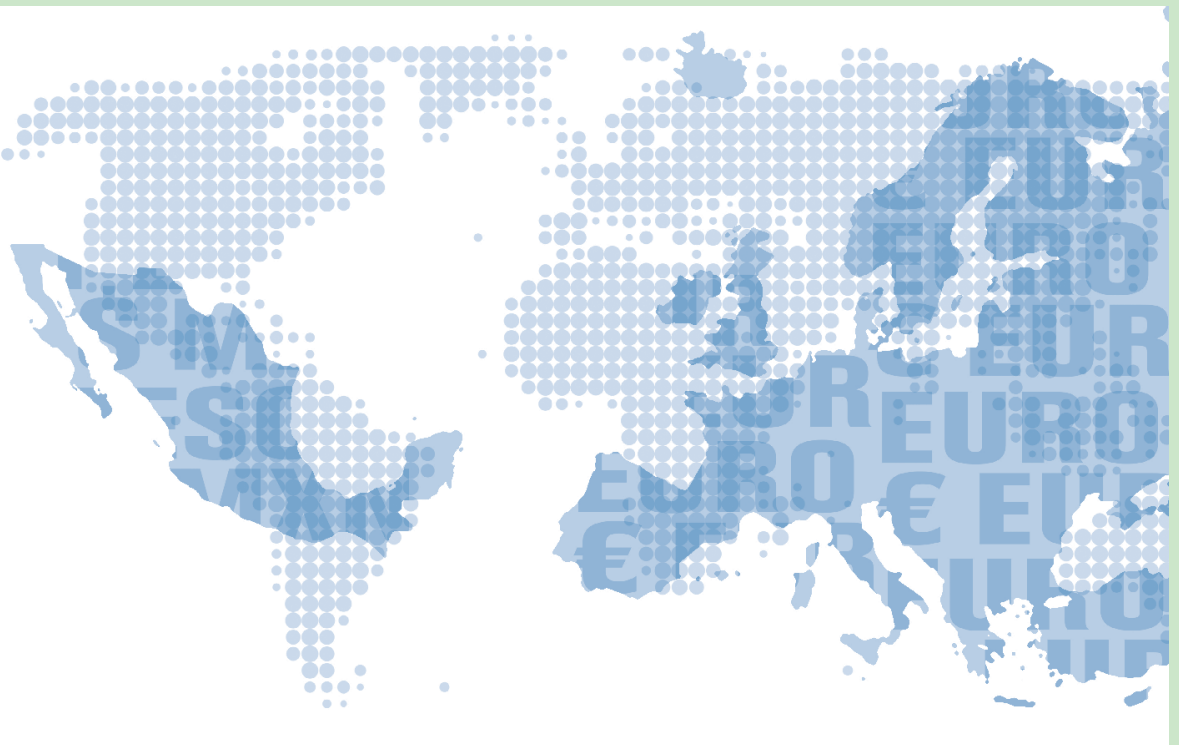

$\mathrm{EE}$

NEW DIRECTIONS IN POST-KEYNESIAN ECONOMICS 


\title{
12. Economic growth and financial development in Mexico: from a virtuous circle of a bidirectional causality to a financial subordination
}

\author{
Teresa López and Eufemia Basilio
}

\subsection{INTRODUCTION}

The historical background of the discussion on the relationship between the financial system and economic growth dates back to the work of Bagehot (1873 [1999]) and Hicks (1969). They argued that the financial system had played a key role in the industrialization of Great Britain, because it facilitated the channeling of large amounts of capital for the creation of major infrastructure projects. Meanwhile, Schumpeter (1911 [2004]) noted that when banks work well they stimulate technological innovation, because they have the information required to locate and finance the best investment projects. He also argued that such projects frequently lead to innovations in production processes and create new products.

A contrary view is that of Joan Robinson (1952), who claimed that company development precedes the development of finance, because the former is the basis for economic growth. According to this economist, economic development stimulates the development of the financial system, because the demand for financing stimulates the creation of new instruments and mechanisms of financing, while the financial system automatically responds to that demand.

The controversy about the causal relationship between the development of the financial system and economic growth did not end with the development and modernization of this system; on the contrary, this and the subsequent deregulation of financial systems in the United States, Great Britain and Canada in the early years of the 1970s paved the way for the revival of the old debate about the aforementioned relationship.

Under the new institutional framework characterized by financial 
deregulation in the industrialized economies, and which would initiate the process of integration of local financial systems, liquidity increased dramatically worldwide. These conditions encouraged the governments of developing countries in general, and Latin America in particular, to undertake reforms in the early 1980s to deregulate their economies, in particular with regard to the liberalization of the external sector and the financial system. These countries included Argentina, Brazil, Chile, Colombia and Mexico, which became the main destination of flows of short-term capital from industrialized countries to developing and emerging economies.

The massive influx of foreign capital was manifested in an increase in indicators of financial depth, such as the M4/GDP ratio (FitzGerald, 2006), which is generally considered an indicator of financial development. However, this indicator and others, such as the increase in the credit portfolio/total assets relationship, was not reflected in increased funding for productive activities in developing economies. By contrast, the opening up of the capital account as a means of financial integration into international financial markets not only led to a contraction of lending to productive activities, but also became one of the main sources of financial instability due to asymmetries in the size and structure of their financial systems compared with those of developed countries. Thus, credit expansion generated financial instability in general, and fragility in the banking market in particular, which led to the exchange rate and banking crises of Mexico (1994-1995) and Brazil (1999).

In the case of Mexico, the entry of large amounts of short-term capital between 1989 and 1994, attracted by the financial reforms and the sale of public enterprises and banks, deepened structural distortions in the functioning of domestic financial channels, such as a poorly developed private securities market and high dollarization of liabilities (Studart, 2003). To this was added the oligopoly power of banks in the credit market, which before financial deregulation was characterized by the financing of private partnerships, granting short-term loans, maintaining high amounts of government securities and excluding low- and middle-income sectors from savings circuits.

The aim of this chapter is to analyse the evolution of the relationship between financial development and economic growth in Mexico for the period 1990-2013. This analysis is placed within the context of financial deregulation and the formal adoption in 2001 of the macroeconomic model of inflation targeting. The hypothesis guiding the analysis argues that during the period that the Mexican financial system was regulated by mechanisms controlling interest rates and selective credit policies, the relationship between the financial system and economic growth formed an interdependent relationship that gave rise to a virtuous circle. This circle 
was broken by deregulation and financial liberalization, since the commercial banks in their quest to increase profit margins favored granting short-term credit to sectors whose sensitivity to changes in interest rates is low, such as consumer credit, and to a lesser extent, the mortgage sector.

The exchange rate and financial crisis of 1994-1995 was the result of these practices and the financialization of the resources of commercial banks, as this increased their investments in synthetic instruments (derivatives, swaps and so on) and government bonds.

The chapter is divided into three sections. Section 12.2 first presents the empirical results of recent research on the relationship between financial development and economic growth in the case of Mexico. Section 12.3 analyses the relationship between the development of the banking system and economic growth in Mexico, by constructing a number of statistical reasons of financial depth and carrying out a Granger causality test. In addition, the behavior of gross fixed capital formation (GFCF) and the structure of bank credit is assessed, in order to understand the weakening of the intermediation function of commercial banks. Finally, Section 12.4 sets out the principal conclusions.

\subsection{FINANCIAL DEVELOPMENT AND ECONOMIC GROWTH IN MEXICO: A REVIEW OF RECENT LITERATURE}

Research by Venegas et al. (2009) on the relationship between financial development, financial repression and economic growth in Mexico for the period 1961-2007 yields results that lead these authors to the following conclusions. (1) Financial development had a positive impact on growth; however, this was small, that is, a weak unidirectional causal relationship between the first and the second is observed. (2) In the long term financial repression caused a negative effect on economic growth. (3) Financial repression has a negative effect on financial development. According to the results of this research, the magnitude of the effect of financial repression on financial development is inversely proportional, but no short-term effect could be identified between financial development, financial repression and economic growth (measured by gross domestic product (GDP)). In other words, neither financial repression nor financial development affected the short-term dynamics of GDP; similarly, financial repression had no impact on financial development in the short term.

These results differ from those of other investigations in the case of Mexico, which used the Time Series methodology, such as the work of Bandiera et al. (2000), who performed an analysis for Chile, Ghana, 
Indonesia, Korea, Malaysia, Mexico, Turkey and Zimbabwe for the period 1970-1994, and whose results show a non-significant positive impact of interest rates on private savings and that financial repression positively influenced financial development, particularly in the increase in private savings. According to these authors, the explanation of the negative impact of financial development on private savings lies in low incomes and the existence of imperfect financial markets.

The study by Arestis and Demetriades (1999) sought to evaluate the effects and the causal link between the institutional conditions, financial policies and economic growth for a representative sample of industrialized and developing countries for the period 1949-1992; in the case of Mexico, the existence of a bidirectional causality between financial development and economic growth was identified. ${ }^{1}$

The study by Rodríguez and López (2009) to assess the causal relationship between financial development and economic growth in Mexico for the period 1990-2004 yielded results that reinforced the previous investigations, identifying the presence of a positive bidirectional causal relationship, although it is unclear what the transmission mechanisms of the positive effects of the financial system to economic activity are.

Finally, research by De la Cruz and Alcántara (2011), using the Vector Autoregressive (VAR) and Error Correction (VEC) techniques for the case of Mexico, assessed the existence of a causal link between bank credit and the main sectors of economic activity and if this is a long-term relationship, for the period 1995-2010. The results lead the authors to present three conclusions.

First, the only credit that impacts the economy is that allocated to consumption and services. While the results do not refute that lending by commercial banks has a positive impact on economic activity, the authors point out that the positive and long-term relationship between credit and economic growth is only sustained by consumer credit. This argument is demonstrated with the existence of a bidirectional causality between the Global Indicator of Economic Activity (IGAE) ${ }^{2}$ and consumer credit for the years 1993-2010. According to the authors, this ratio is an indicator of the penetration of banking into consumption, which has been recorded since the early 1990 s.

Second, it was found that the growth of consumer credit generated a credit bubble prior to the 2009 crisis. In this regard, the authors argue that the increase in consumer credit in conditions of low economic growth is one factor that underlies financial instability. Hence, they indicate the need to establish mechanisms to regulate the banking system.

Third, there is limited interaction between the real sector of the economy and the financial system due to two factors: (a) the banking credit granted 
to the productive sectors registered a downward trend compared with consumer credit and (b) the yield of economic activity has been modest and weak.

This research shows that the positive effect of consumer credit on domestic demand - and to a lesser extent mortgage lending induced by federal government policy to stimulate economic growth by constructing social housing - is an unsustainable relationship in the long run, because this type of credit by itself does not generate large-scale multiplier effects required to reactivate economic activity at the macroeconomic level.

Consequently, to the extent that consumer credit increases at a faster rate than the growth in income and employment, this private banking strategy will become a source of financial instability.

Just as in the case of empirical research on the international level, research into the relationship between financial development and economic growth in the case of Mexico is not conclusive. This raises, first, the need for a more disaggregated econometric analysis and, second, to incorporate other variables to measure both financial development and the impact of banking credit on economic growth.

\subsubsection{The Relationship Between Financial Development and Economic Growth: A Bidirectional and Historical Relationship}

In the absence of strong and sufficient empirical evidence that allows us to accept that financial development has a unidirectional and positive effect on economic growth, we can argue that development of the financial system per se does not guarantee economic growth, and nor does it ensure that savings in the economy are converted into financing of investment.

Considering the low level of growth registered by the Mexican economy since 1996, resulting from the application of a pro-cyclical fiscal policy, which is part of the regime of inflation targeting to keep inflation low by shrinking domestic demand, we can argue that economic growth depends on several factors and not only on the development of the financial system. Of course, one of these factors is financing from banks, but other equally important - or perhaps even more so - factors exist, such as the growth of effective demand and employment, because these factors generate positive earnings expectations, which in turn determine new investment decisions.

In accordance with the foregoing, we propose that the causal link between the financial development and growth of an economy is the result of a process that is mutually determined, that is, which is bidirectional. In this regard, we share the view of Schumpeter (1911 [2004]) who held that when banks operate 'well', that is, when credit reaches all the productive sectors, and especially the sectors driving growth and technological 
innovation, the financial system becomes important for economic growth. In addition, we agree with the approach of Joan Robinson (1952) who argued that development of firms precedes the development of finance, because, according to the Keynesian framework she employed, the development of firms implies economic growth, and this entails the expansion of investment. To the extent that the effective demand rises, the profits of the companies will be realized and, as a result, the reinvestment of profits will increase and internal savings, as a remainder, will rise. This will promote the development of financial systems in a manner that will depend on the structure and historical development of each country.

Historically, economic development stimulated the modernization of financial systems, as demand for financing from companies induced banks to create new instruments and funding mechanisms with the aim of generating greater liquidity and reducing the lag time between the deposits (usually short term) and credit (usually medium and long term). This interdependent relationship established a virtuous circle, that is, a process with bidirectional causality, which was strengthened with the establishment of mechanisms for monitoring and control of financial operations in general and banking in particular.

This view is implicit in the historical analysis of Chick (1993) on the evolution of banks, to understand the endogenous nature of money and the institutional and policy changes of central banks. This approach is complemented by the contributions of Toporowski $(2001,2013)$ on the historical character of technological innovations in the financial system, which are inherent to the development of capitalism.

The virtuous circle between financial development and economic growth is broken by the removal of regulatory and supervisory mechanisms for financial activities. For developed economies, the interdependence between financial development and economic growth lasted nearly four decades, if we consider that in 1933 the Glass-Steagall Act (Banking Act) came into force in the United States, and that the regulations contained in this Act were weakened in the early 1970 s to make way for the liberalization of its financial system. ${ }^{3}$

In the case of developing economies, this relationship held for more than three decades, as the financial regulatory systems were generally established in the early 1940s as part of the policies adopted to boost the process of industrialization of these economies, and these were eliminated in the first years of the 1980s, in the context of the debt crisis experienced by several economies in Latin America, including Mexico.

The policies of deregulation and liberalization of national financial systems by eliminating the prudential oversight and mechanisms of control over deposit and lending rates and channeling of credit to priority 
economic activities, caused the bidirectional relationship that had formed between growth economic and modernization of the financial system to became a vicious circle, as the new technological innovations that marked the development of financial systems led to a reduction in funding for productive investment. In other words, the development of the financial system was separated from the financing needs of the real economy.

\subsection{LIBERALIZATION AND FINANCIAL DEPTH VERSUS FINANCING ECONOMIC GROWTH IN MEXICO}

This section analyses a number of statistical and graphical indicators on the relationship between financial development and economic growth in the case of Mexico, in the context of financial deregulation and the full adoption in 2001 of the macroeconomic model of inflation targeting.

\subsubsection{Monetary Stability with Low Economic Growth: A Macroeconomic View}

Over the long period between 1950 and 1976, under a regulated financial system and countercyclical management of fiscal policy centered on public investment in basic infrastructure and the production of basic goods and services through public companies, the Mexican economy grew at a rate of between 4 and 7 percent, as an annual average. During the period 1958-1970, known as the 'stabilizing development', sustained growth meant that monetary stability was achieved, accompanied by low primary deficits of 2 percent as a proportion of GDP, as an annual average (López, 2010).

In a macroeconomic context marked by severe recession and financial fragility generated by the oil boom years of 1979-1982, which led to the outbreak of the debt crisis, the rhythm of stable and sustained growth was interrupted. Beginning in 1983, stabilization policies and orthodox macroeconomic adjustment were implemented to address the severe recession and inflationary pressures. In parallel, economic reforms were implemented aimed at deregulating the economy, and specifically the financial and external sectors.

Liquidity problems and restrictions on access to external financing exacerbated the recessionary and inflationary effects generated by the external debt crisis of 1982. In 1988, structural reforms accelerated under the argument that it was necessary to create the institutional and economic conditions to permit the adoption of a macroeconomic strategy based on export growth and on the dynamics of the private sector of the economy. 
This meant accelerating the economic and institutional reforms that were initiated in 1983, that is, the deregulation of the financial system and liberalization of the external sector, in order to make progress with the elimination of state involvement in economic activity (Solís, 1996).

From 1983 to 2013, GDP has grown at a low and irregular rate, since the phases of expansion are very short in duration, and growth has been no more than 2 percent as an annual average, while the recessionary phases are very deep with a longer recovery time; without approaching the rate of growth recorded in the period of stabilizing development. The stability of prices and balance in public finances recorded since 2000 is the result of the containment of economic growth by way of reduced domestic demand.

\subsubsection{The Vicious Circle, Financial Depth and Low Financing of Productive Activities}

Various indicators have been constructed to measure the degree of financial development (M4/GDP, portfolio credit/total credit, total credit/total assets and so on). For the purposes of this chapter we have taken as a proxy measure the M4/GDP ratio in nominal terms, agreeing with the arguments of Asteriou and Price (2000) insofar as M4 is a broad measure of money and the (M4/GDP) index increases (decreases) over time if the development of the financial system accelerates (decelerates) compared to the real sector of the economy.

Figure 12.1 shows that there is no relationship between the natural logarithm (Ln) of the M4/GDP ratio and real GDP growth, and this decoupling has deepened since 2000. Since 2005, the depth and development of the financial system resumes the upward trend that began in 1990, with the exception of 1994-1995 and 2002-2004, in response to the acceleration of the deregulation process in the sector. In nominal terms, the M4/GDP ratio was 35.75 on average in 1990, and 70.45 percent in 2013. Considering this extraordinary increase, we might say that the Mexican financial system has undergone a high rate of development; however, this contrasts with the weak and uneven growth of GDP per capita and total GDP. The latter recorded sharp declines in 1995, 2001, 2009 and 2013, while the natural logarithm of GDP per capita shows an accelerated declining trend. The improvement recorded by this indicator over the years in which the growth rate of real GDP fell is a result of the combination of an increase in the population (numerator) and a drastic drop in the real growth rate of GDP (denominator). This is demonstrated by the fact that when the GDP grows, the GDP per capita decreases.

In general, this latter indicator registered a downward trend over the period 1990-2013, as a result of low and irregular growth of GDP. 


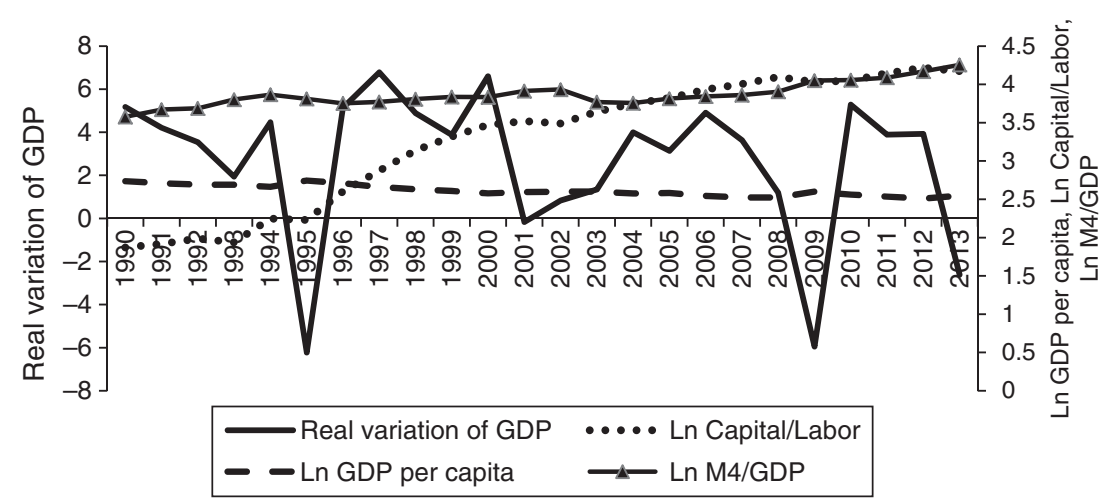

Note: M4: broad monetary aggregates.

Source: Authors' calculations using data from INEGI and the Bank of Mexico.

\section{Figure 12.1 Mexico: economic growth in terms of GDP and the capital and labor ratio}

As for the capital/labor ratio, estimated with the natural logarithm of the ratio of GFCF and the economically active population, it shows rapid growth during the 1994-2001 period, and following a fall in 2002, after 2003 it indicates weak growth with a tendency to stagnation (Figure 12.1).

After the currency and financial crisis of 1994-1995, the GFCF, as a share of GDP, has seen a gradual decline; in 1990, it accounted for 29 percent, while by 2000 this percentage drops to 27 percent. Over 13 years this trend has increased: from 26 percent in 2001, the percentage dropped to 21 percent in 2013. This suggests a direct and positive relationship between growth of GFCF and GDP, with a certain lag shown by the first with respect to changes in GDP, which is explained by the periods of maturation of new fixed assets incorporated into economic activity (Figure 12.2).

These data lead us to argue that, on the one hand, the contraction of GFCF as a share of GDP has been one of the determinants of the low and irregular growth of the Mexican economy and, on the other, that the greater depth or development of the financial system, as measured by the M4/GDP ratio, has led to its detachment from the real sector of the economy; that is, the Mexican banking system has ceased to fulfill the role of financing investment.

Following the exchange rate and financial crisis of 1994-1995, commercial banks increased the rationing of credit to productive activities. This reduction was due to several factors. At the microeconomic level, 

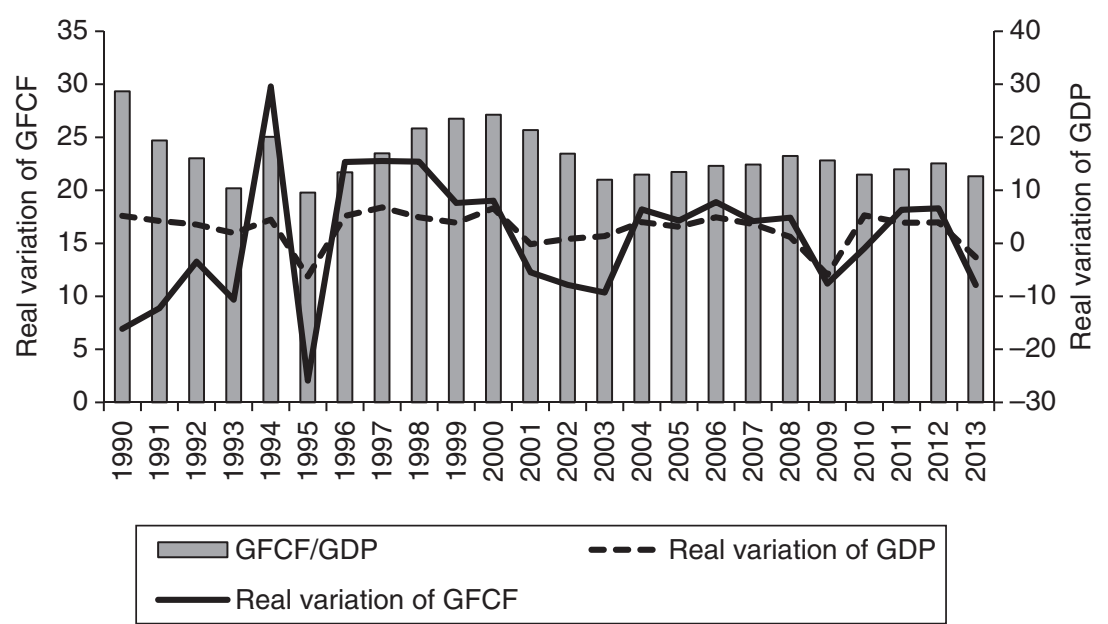

Source: Authors' calculations using data from INEGI and the Bank of Mexico.

Figure 12.2 Mexico: economic growth in terms of GDP and gross fixed capital formation

commercial banking reactivated its strategy of short-term profit by increasing credit to highly profitable sectors, such as consumer credit. The high moral risk of these sectors is more than offset by high interest rates and the fees charged by them, particularly credit cards. These conditions and the low elasticity of this type of credit to changes in interest rates have turned consumer credit into one of the main sources of income for commercial banking. This is despite the high levels of non-performing loans that are often recorded with this type of credit.

At the macroeconomic level, the policy of sterilized intervention in the foreign exchange market by the Bank of Mexico, intended to avoid sudden variations in the level of the monetary base, and thus to maintain a stable nominal exchange rate has contributed to the contraction of credit to productive sectors. In this sense, the issuance of government bonds has not only become an important component of the monetary policy of inflation targeting, but also become a source of high and secure profits for commercial banks, since the rate yielded by these instruments is higher than the external rate.

This, coupled with the uncertainty about the recovery of economic activity, generated largely by the practice of pro-cyclical fiscal policy and high lending rates, are two factors that inhibit the demand for credit by companies. Table 12.1 shows that credit to the private sector increased in 


\section{Table 12.1 Mexico's commercial banking distribution of total credit, ${ }^{\mathrm{a}}$ 1990-2013, percentage structure}

\begin{tabular}{|c|c|c|c|c|c|c|c|}
\hline \multirow[t]{2}{*}{ Year } & \multicolumn{6}{|c|}{ Total Private sector } & \multirow{2}{*}{$\begin{array}{c}\text { Other } \\
\text { sectors }^{\mathrm{c}}\end{array}$} \\
\hline & Total & $\begin{array}{l}\text { Total } \\
\text { private } \\
\text { sector }\end{array}$ & $\begin{array}{l}\text { Agricultural } \\
\text { sector }\end{array}$ & $\begin{array}{l}\text { Industrial } \\
\text { sector }\end{array}$ & $\begin{array}{c}\text { Services } \\
\text { sector, other } \\
\text { activities and } \\
\text { consumption }\end{array}$ & $\begin{array}{l}\text { Housing } \\
\text { credit }\end{array}$ & \\
\hline 1990 & 100.0 & 91.56 & 11.54 & 35.85 & 34.81 & 9.35 & 8.44 \\
\hline 1993 & 100.0 & 96.72 & 9.35 & 30.23 & 35.54 & 21.60 & 3.28 \\
\hline 1996 & 100.0 & 86.08 & 5.47 & 24.37 & 31.81 & 24.43 & 10.79 \\
\hline 1999 & 100.0 & 72.25 & 4.06 & 20.20 & 24.69 & 23.30 & 25.83 \\
\hline 2002 & 100.0 & 65.24 & 2.15 & 16.70 & 29.89 & 16.51 & 33.86 \\
\hline $2004 *$ & 100.0 & 68.92 & 2.07 & 16.28 & 36.52 & 14.04 & 31.08 \\
\hline 2005 & 100.0 & 73.75 & 1.93 & 15.51 & 41.85 & 14.46 & 26.25 \\
\hline $2008 * *$ & 100.0 & 85.13 & 1.61 & 18.43 & 48.51 & 16.59 & 14.87 \\
\hline 2011 & 100.0 & 81.28 & 1.54 & 20.75 & 41.81 & 17.18 & 18.72 \\
\hline 2013 & 100.0 & 81.69 & 1.77 & 19.94 & 43.69 & 16.30 & 18.31 \\
\hline
\end{tabular}

Notes:

a. From July 1995, includes subsidiaries of foreign banks operating in Mexico. Information after December 2004 does not include data from banks in the process of liquidation or bankruptcy.

b. Until 1994, the heading 'Commerce' was used instead. In 1994, using a new methodology the heading 'Consumption' was created. In order to construct a series for 1990-2013, we include in the heading 'Services sector and other activities' the credit for Commerce for the years 1990-93. This accounts for part of the increase in the share of total credit by the 'Services sector and other activities' for the years 1990-93.

c. This heading includes the domestic financial sector, not including inter-bank loans; the public sector from 1994, where credit to the government includes governmental programs to support debtors, loans to public administration, defense and social security services of the federal government; ADE support programs, state and municipal governments, the government of the Federal District and public, state and decentralized bodies and corporations; it refers to the financing granted to longterm productive infrastructure projects both in Mexican and foreign currencies and includes PIDIREGAS, IPAB and FONADIN and the Fideicomiso Fondo Nacional de Infraestructura D.O.F. 7/02/2008 (previously FARAC), the external sector, including services for international and offshore financial and non-financial bodies, and interbank loans.

* Information after December 2004 does not include data from banks in the process of liquidation or bankruptcy;

** from March 2008 commercial banking is presented consolidated with its subsidiaries the SOFOM Regulated Entities (ER) and credit cards (Tarjetas Banamex, Santander Consumo, Ixe Tarjetas and Sociedad Financiera Inbursa), which increases the figures for consumer credit. In addition, as a result of this consolidation, the balances of credit granted to non-bank financial intermediaries are reduced.

Source: Authors' calculations using data from the Bank of Mexico. 
the early 1990s; however, following the 1994-1995 banking crisis a gradual decline was recorded, until 2004. In 1990, credit to the private sector accounted for 92 percent of total credit provided by commercial banks; by 2004 this percentage had dropped to 69 percent, that is, a fall of 23 percentage points in 14 years. Although a slow recovery in credit to the private sector has been observed since 2005, it has not recovered the level of 1990, and by 2013 credit to the private sector stood at 82 percent.

The contraction of credit was more severe for the industrial and agricultural sectors - particularly for the latter - while the services and consumer sectors have maintained a high share of total bank credit. Nevertheless, lending to these sectors has also fallen; from 82 percent in 1990, it fell to 65 percent in 2013 (Table 12.1). This reduction coincides with an increase in holdings of government bonds and investments in synthetic instruments (derivatives, swaps and so on) by commercial banks.

In short, the current structure of Mexican commercial banking has the following characteristics: (1) the dominance of foreign capital and a high concentration of assets and liabilities in the four largest banks; (2) the consolidation of the dual power of the market: the oligopolistic power in the credit market that allows it to set rates above the rates of government securities and foreign lending rates, and the oligopsonistic power of the deposits market to set deposit interest rates lower than government bonds; (3) the strengthening of their rentier and speculative character, which has become a permanent source of financial instability; (4) weak financial intermediation with productive activities and high profit margins despite lowering intermediation costs; and (5) increasing dollarization of bank liabilities.

\subsubsection{Empirical Evidence on the Causal Relationship Between Financial Development and Economic Growth}

Table 12.2 presents the results of the Granger causality tests on the relationship between financial development and economic growth, the first measured by the M4/GDP ratio, and the second by GDP, for the period 2000-2013. ${ }^{4}$ The result for the causal link between M4 and GDP for the period 1990-2013 shows that the $\mathrm{x}^{2}$ statistic is significant at 5 percent, meaning that M4 cannot be considered exogenous. Since it meets the requirement for endogeneity of this variable, we can argue that it is GDP growth that determines financial development.

The result for the ratio between bank assets - which is another variable used to measure financial development - and GDP per capita, for the period 2000-2013, also shows that the causality runs from the latter to the former, because, just as in the previous case, the $\mathrm{x}^{2}$ statistic is significant at 


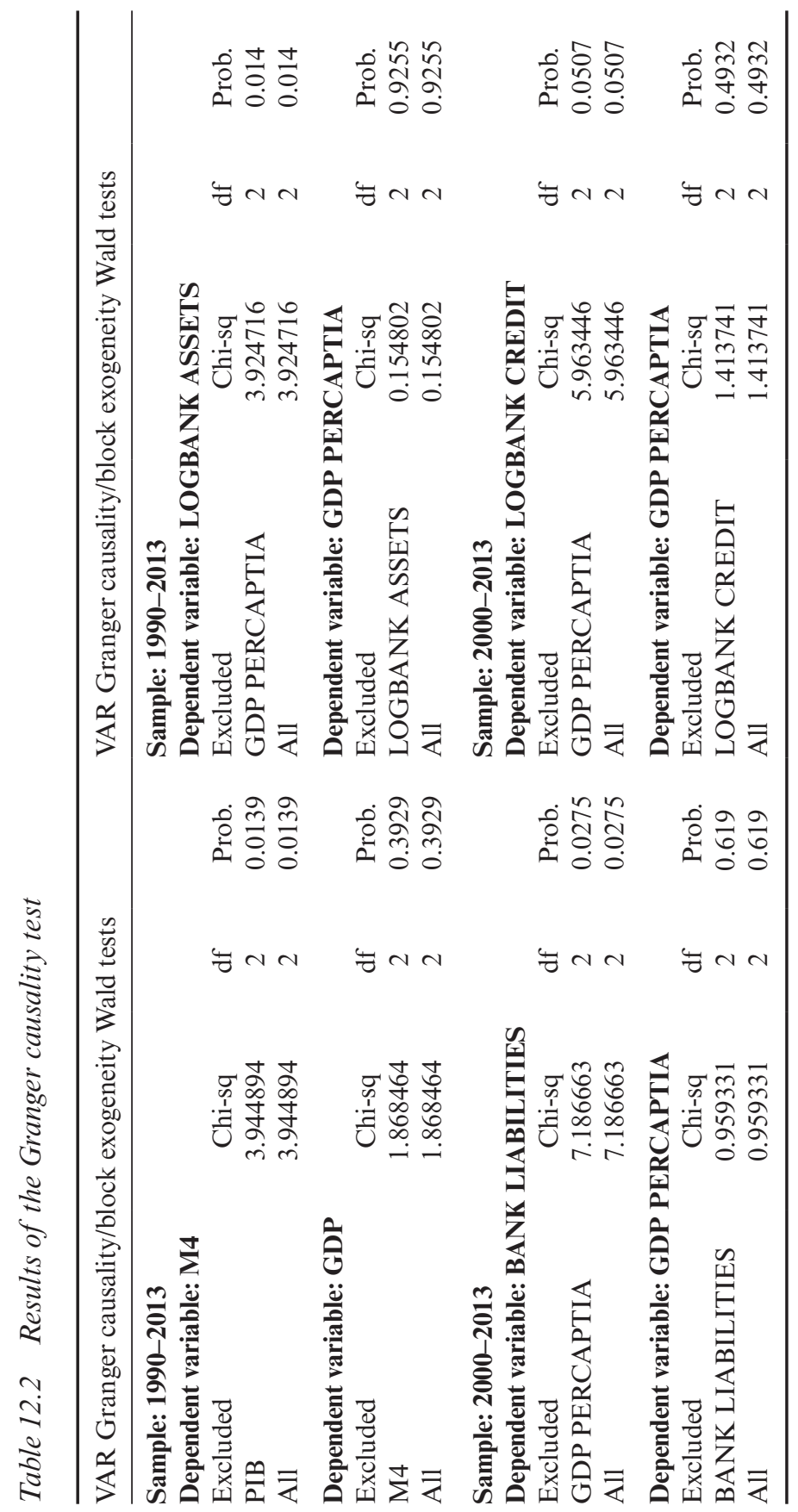


5 percent. This implies that bank assets cannot be considered exogenous and, therefore, the requirement for endogeneity of the bank assets variable is met.

The result for the relation between bank liabilities, as an indicator of financial development, and GDP, with the probability of this causality being significant at 5 percent, again shows that economic growth is what determines economic activity.

Finally, the result for the causal link between bank credit, another indicator of financial development, and GDP per capita is presented, the $\mathrm{x}^{2}$ statistic being significant at 5 percent, as in the three previous cases, shows that the causality runs the GDP per capita to bank credit, which means that bank credit cannot be considered exogenous, and hence the requirement of endogeneity of this variable is met.

Based on these results of the Granger causality tests, we can argue that in the case of Mexico, the banking sector was no longer a major source of financing for economic growth during the years 2000-2013. Figure 12.3 shows the spread between GDP per capita and credit to the private sector, which accounts for the decoupling of the development or depth of the banking system and the financing of economic activity in Mexico.

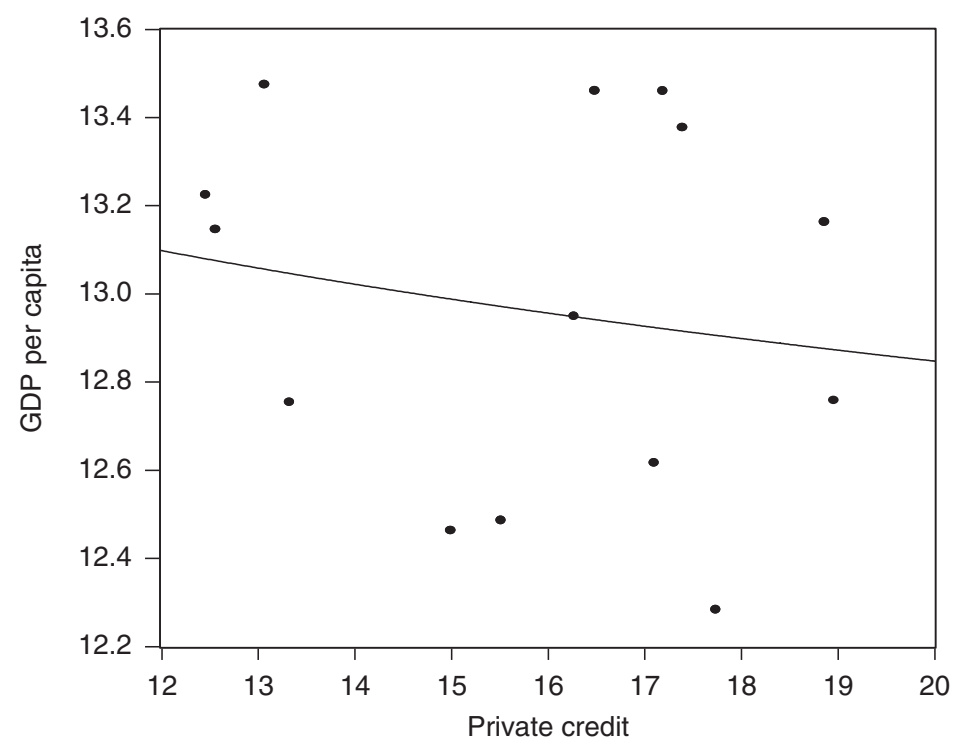

Source: Authors' own work using econometrics package Eviews 8.

Figure 12.3 Mexico: private credit and GDP per capita 
Considering that this lack of coordination between the financial sphere and the real economy arises in the context of increasing foreign ownership of commercial banks, and coincides with the acceleration of the modernization process and depth of the financial system, it is clear that the development of the financial system, if we understand that to mean modernization and depth, is not in itself a guarantee of increased financing for economic growth, and nor does it ensure that savings in the economy are converted into financing for investment. Also, the expansion of consumer credit and mortgages in a context of low growth and high unemployment represents a source of financial instability, because their multiplier effects are very limited and temporary.

The pro-cyclical practice of fiscal policy under the inflation targeting regime, which in Mexico was adopted in full in 2001, has greatly contributed to the formation of a vicious circle between financial development and economic growth. On the one hand, the low and uneven economic growth justifies commercial banks rationing credit to businesses, and these in turn reducing their demand for credit due to uncertainty about future earnings. On the other, this situation warrants commercial banks expanding consumer credit and increasing their investments in government bonds and derivative instruments, which provides high yields.

These results allow us to argue that there is a bidirectional relationship between financial development and growth, and that this can be positive or negative. The latter question will depend on macroeconomic behavior, economic policy - particularly fiscal and monetary policies - and institutional factors such as the existence of a regulatory framework and oversight of financial transactions in general, and banking operations in particular.

\subsection{CONCLUSIONS}

The deregulation of the Mexican financial system caused a contraction of credit for productive activities and deepened the rentier and speculative character of Mexican commercial banks. The latter ceased to fulfill their historic intermediary role, that is, for the financing of productive activities and therefore economic growth.

The concentration of assets and liabilities in four major financial groups led by foreign capital is the result of the policies of deregulation and liberalization, which assumed a priori that the removal of control and oversight mechanisms would automatically lead to an increase in domestic and foreign savings, and efficient integration of the Mexican financial system into international financial markets. 
A review of the literature on the relationship between financial development and economic growth both generally and in the case of Mexico produces inconclusive results suggesting that the financial system determines economic growth. In the case of Mexico, the reducing or rationing of credit to productive activities is parallel to the process of financial liberalization.

The reduction of bank credit to productive sectors, such as the industrial and agricultural sectors, in the context of weak growth caused by the macroeconomic policy of inflation targeting, establishes the vicious circle linking modernization and liberalization of the financial system and low economic growth. Low expectations about the future growth of the economy discourage new investment decisions, a situation that is heightened by high interest rates and credit rationing productive activities.

In a context of low GDP growth and employment, provision of consumer and mortgage credit is not the best strategy to induce growth in domestic demand, because their multiplier effects are weak in these conditions, and in the medium term they can become a source of financial instability, because consumer and mortgage credit grows at a faster pace than income, which will raise the ratio of non-performing loans held by commercial banks.

\section{NOTES}

1. The sample of countries comprises France, Germany, United Kingdom, Japan, United States, South Korea, India, Greece, Spain, Turkey, Mexico and Chile. In the case of Mexico, the period was 1951-1992.

2. The Global Indicator of Economic Activity (IGAE) shows the evolution of the real sector of the economy in the short term. IGAE monthly figures are available from January 1993.

3. Strong criticism of the Glass-Steagall Act, generally known as the Banking Law Act, considering it an obstacle to the adjustment of the US banking system to the development of international financial markets, eventually led to its repeal in November 1999, and the approval of the Financial Services Modernization Act, also known as the Gramm-LeachBliley Act.

4. It is important to note that the limited availability of data for a short period of analysis (2000-2013) did not allow us to build a vector autoregression (VAR) model, which is generally used for assessing causality between financial development and economic growth. For this reason, we used the simple Engler-Granger technique to allow us to strengthen the statistical and graphical analysis presented. The Granger causality test assumes that the relevant information for the prediction of the variables to determine, $\mathrm{X}$ and $\mathrm{Y}$, is contained solely in the time series data on these variables. The test involves the following estimates:

$$
\begin{aligned}
& Y_{t}=\sum_{i=1}^{n} \alpha_{i} X_{t-1}+\sum_{j=1}^{n} \beta_{i} Y_{t-j}+u_{1 t} \\
& X_{t}=\sum_{i=1}^{n} \gamma_{i} X_{t-1}+\sum_{j=1}^{n} \delta_{i} Y_{t-j}+u_{2 t}
\end{aligned}
$$


where it is assumed that the perturbations $u_{1 t}$ and $u_{2 t}$ are not correlated. Equation (12.1) postulates that the current value of $\mathrm{Y}$ is related to past values of $\mathrm{Y}$, as well as with those of $\mathrm{X}$. Equation (12.2) postulates a similar behavior for X. Four possible types of Granger causality are distinguished (Gujarati, 2001). (1) Unidirectional causality from $X$ to $Y$, where the estimated coefficients on the lagged $\mathrm{X}$ in (12.1) are statistically different from zero when considered in a group, that is, $\sum \alpha_{i} \neq 0$ and the set of estimated coefficients on the lagged $Y$ in (12.2) is not statistically different from zero, that is, $\sum \alpha_{i}=0$. (2) Conversely, the unidirectional causality of $Y$ to $X$ exists if the set of coefficients of the lagged $X$ in (12.1) are not statistically different from zero, that is, $\sum \alpha_{i}=0$ and the set of coefficients of the lagged $\mathrm{Y}$ in (12.2) is statistically different from zero, that is, $\sum \alpha_{i} \neq 0$. (3) Feedback, or bilateral causality, is what occurs when the coefficient sets of $\mathrm{X}$ and $\mathrm{Y}$ are statistically significant, and different from zero, in both cases. (4) Independence exists when the sets of coefficients X and Y are not statistically significant in both cases.

\section{REFERENCES}

Arestis, P. and P. Demetriades (1999), 'Finance and growth: institutional considerations, financial policies and causality', Zegreb International Review of Economics and Business, 2, 37-62.

Asteriou, D. and S. Price (2000), 'Financial development and economic growth: time series evidence for the case of UK', Ekonomia, 4(2), Cyprus Economic Society and University of Cyprus, Winter, 122-41.

Bagehot, W. (1873), Lombard Street: A Description of the Money Market, London: Armstrong and Company. London, reprinted in 1999, New York: Wiley, available at http://www.gutenberg.org/cache/epub/4359/pg4359.html, accessed 8 July 2015.

Bandiera, O., G. Caprio, P. Honohan and F. Schiantarelli (2000), 'Does financial reform raise or reduce saving?', Review of Economics and Statistics, 82(2), 239-63.

Chick, V. (1993), 'The evolution of the banking system and the theory of monetary policy', in S.F. Frowen (ed.), Monetary Theory and Monetary Policy: New Tracks for the 1990s, New York: Palgrave Macmillan, pp. 79-92.

De la Cruz, J.L. and J.A. Alcántara (2011), 'Crecimiento económico y el crédito bancario: Un análisis de causalidad para México', Revista de Economía, XXVIII(77), July-December, Mexico, 13-38.

FitzGerald, V. (2006), 'Models of saving, income and the macroeconomics of developing countries in the Post-Keynesian tradition', in P. Arestis, J. McCombie and R. Vickerman (eds), Growth and Economic Development: Essays in Honour of A.P. Thirlwall. Cheltenham, UK and Northampton, MA, USA: Edward Elgar, pp. 247-62.

Gujarati, D.N. (2001), Econometría, 3rd edn, Mexico: McGraw Hill.

Hicks, J. (1969), A Theory of Economic History, Oxford: Clarendon Press.

López, T. (2010), 'La política fiscal y el crecimiento económico México. Crecimiento con estabilidad monetaria versus estancamiento con estabilidad monetaria', in G. Mántery and N. Levy (eds), Cincuenta años de políticas financieras para el desarrollo en México (1958-2008), Mexico City: DGAPA-UNAM and Plaza y Valdes, pp. 75-105.

Robinson, J. (1952), 'The generalization of the general theory', in The Rate Interest and Others Essays, London: Macmillan, pp. 69-142. 
Rodríguez, D. and F. López (2009), 'Desarrollo financiero y crecimiento económico en México', Revista Problemas del Desarrollo, 40(159), Instituto de Investigaciones Económicas, UNAM, Mexico City, 39-60.

Schumpeter, J. (1911), The Theory of Economic Development, 10th edn reprinted in 2004, New Brunswick, NJ: Transaction Publishers.

Solís, L. (1996), Crisis económico-financiera 1994-1995, Mexico City: El Colegio Nacional and Fondo de Cultura Económica.

Studart, R. (2003), 'Integración financiera, inestabilidad y desempeño macroeconómico en los noventa: posibles conexiones perversas', in G. Mántey and N. Levy (eds), Financiamiento del desarrollo con mercados de dinero y capital globalizados, Mexico City: Miguel Ángel Porrúa and ENEP-Acatlan-DGAPA, pp. 43-68.

Toporowski, J. (2001), 'El factor crítico de las finanzas en la economía del siglo XX', Revista Momento Económico, 113, Instituto de Investigaciones Económicas-UNAM, Mexico, January-February, 2-15.

Toporowski, J (2013), 'El neologismo como una innovación teórica en la economía: El caso de la financiarización', in N. Levy and T. López (eds), Financiarización $y$ modelo de acumulación. Aportes desde los países en desarrollo, Facultad de Economía-UNAM, Mexico, pp. 31-46.

Venegas-Martinez, F., M. Tinoco-Zermeño and V. Torres Preciado (2009), 'Desregulación financiera, desarrollo del sistema financiero y crecimiento económico en México: Efectos de largo plazo y causalidad', Revista Estudios Económicos, 24(2), July-December, Mexico, 249-83. 